\title{
Indonesian Agricultural Law Politics in Facing Global Challenges
}

\author{
Novit Kosmiko ${ }^{1}$, Zudan Arief Fakrulloh ${ }^{2}$ \\ \{NovitKosmico@yahoo.com¹, cclsis@yahoo.com²\} \\ Universitas Borobudur, Jakarta, Indonesia ${ }^{1,2}$
}

\begin{abstract}
The construction of agrarian arrangement in Indonesia is as yet procuring with numerous issues which incorporate the change of horticultural land to non-rural land, the low level of the ranchers' government assistance, just as the land change strategy. To unwind the reasons for these issues, this examination plans to first, talk about the governmental issues of agrarian law in Indonesia from the Old Order period to the Reformation, and second, to present suggestions for working on the advancement of rural law legislative issues to confront the worldwide difficulties. This review utilizes a standardizing lawful examination technique by exploring the legal methodology and authentic methodology. The examination reasoned that, first, during the Old Order the political bearing of the rural area was underlined on the ilnventory of farming and ranch land. During the New Order period, the political bearing of the rural area was separated into two, to be specific, the course of food power and semi-modern horticulture. During the change time frame, the strength of the impact of unfamiliar free enterprise in the enactment. Second, the thoughts proposed to confront the worldwide difficulties are by building a lawful strategy for farming dependent on monetary popular government as started by Bung Hatta.
\end{abstract}

Keyword: Lawful approach; horticulture; government; globalization

\section{Preliminary}

Indonesia is a country characterized by the archipelago which has a strategic location and abundant natural wealth. Soekarno described Indonesia as a "sea country dotted with islands". The breadth of the oceans and the fertile archipelago make Indonesia a country rich in natural resources (SDA). The strategic location and abundant natural resources make Indonesia a "meeting point for maritime exploration that bring various currents of civilization" as well as a magnet for other nations to explore the wealth of Indonesia's natural resources. This fact can be seen from the colonial goal carried out by the Dutch to control Indonesian spices and make Indonesia a source of funding for European wars.

The above description confirms that Indonesia is a fertile country. The fertility of Indonesia's soil makes Indonesia an agrarian country because it has great agricultural potential and extensive agricultural land. Excellence in agriculture certainly has the potential to improve the country's economy in addition to meeting domestic food needs. Food needs are one of the 
crucial needs in daily life. Food has a vital significance and job for the endurance of a country's life. The accessibility of food that is more modest than the need can make financial shakiness. Different social and political unrest

The name "Indonesia" was first introduced by James Richardson Logan, a British anthropologist in his work entitled " The Ethnology of the Indian Archipelago." Richardson's work was distributed in the Journal of the Indian Archipelago and Eastern Asia, distributed in 1850 in Singapore. The term Indonesian name by Richardson was later popularized by Adolf Bastian. According to Yudi Latif, the term commonly used to describe the Indonesian state is "archipelagic state", which contains a land bias. This is more in line with the term archipelago. Archipelago comes from the words arch/archi which is power and pelago/pelagos which means ocean which when combined into the power of the ocean. [1] Based on Soekarno's thought pattern, Indonesia deserves to be called Nusantara or Archipelago. Furthermore, Soekarno's opinion is in line with Mohammad Hatta's statement. This can be seen in the thoughts of Mohammad Hatta which describes the correlation between natural wealth, strategic position, and the cultural development of the people of the archipelago can be disrupted if food security is compromised.

This critical condition can endanger national stability and undermine the ruling government.[1] Efforts to meet food needs through food security policies must become a central issue in building people's welfare. The starting point for the development of agricultural law politics must be based on a plan to build a sustainable agricultural system. This effort begins with the development of a sustainable agriculture of the system to improve the quality of life.8 Agrarian administration in Indonesia is as yet dangerous. The issues include: first, the transformation of horticultural land into non-agrarian land. In view of information from the Central Statistics Agency (BPS) from 2009 to 2013 there was a restricting of horticultural land as portrayed in the accompanying table. [3]

The information shows that the limiting of agrarian land is progressively broad aside from land that is utilized for cultivating in fields. The majority of land conversion in the agricultural sector is used for the purpose of clearing residential land due to higher population growth. One of the reasons for the decrease in agricultural land is none other than.[3] For example, as happened in Bekasi-Cikarang based on data from the Bekasi Regency Office, agricultural land shrinks by around 1,500 Ha per year, in 2014 there was still an area of 52,000 Ha, while in 2017 it was reduced to $48,000 \mathrm{Ha}$. The agricultural land has been turned into a residential or industrial area.[4]

Third, the issue of land change that has not been finished. Though the land change is expected to work on the design of land disparity, reestablish land as a method for agrarian creation which affects expanding usefulness and increasing the expectation of living of ranchers. Nonetheless, the Agricultural Census in 2013 really showed that consistently Indonesia loses $0.25 \mathrm{Ha}$ of horticultural land, because of changing its capacity to non-agrarian land.[4] likewise, there is a lopsidedness between land proprietorship and control among ranchers and different areas, making the deficiency of the rural area different areas. progressed modern sector.

The three problems that have been stated above show that the regulation of agricultural policy in Indonesia has resulted in many problems both at the conceptual and practical levels. This condition certainly hinders Indonesia's vision to achieve food sovereignty. There has also not been a strong onslaught of competition from foreign parties through free markets and imports of food ingredients. This condition is certainly a threat for the people of Indonesia, especially for farmers. Legal politics in the context of this research is understood as a goal to be achieved and a means to achieve goals.15 Agricultural legal politics shows the direction to 
realize the legal regulation of the agricultural sector in Indonesia. The objectives to be achieved from the management of the agricultural sector are certainly related to efforts to protect and empowering the agricultural sector from the threat of free market vortex and international trade through the World Trade Organization (WTO).

Free markets and international trade are forms of economic globalization that are thick with the spread of liberalism.16 Therefore, it is necessary to conduct a study on "Indonesian Agricultural Law Politics in Facing Global Challenges".

\section{Formulation of the Problem}

The formulation of the problem in this study includes:

1. How is the legal politics of the agricultural sector in Indonesia?

2. How to build the right agricultural law politics in Indonesia in facing global challenges?

\section{Research Purposes}

This review intends to distinguish and dissect the legitimate governmental issues of the rural area in Indonesia from the old request, new request, to the change time, just as modify the premise of lawful political speculation dependent on equity in Indonesia to reestablish the government assistance of ranchers and satisfy homegrown food saves dependent on monetary majority rules system, in the midst of the impacts and difficulties of globalization.

\section{Research Methods}

This exploration is remembered for the typology of regulating lawful examination which is investigated with a resolution approach and a chronicled approach. The authoritative methodology is completed by analyzing the laws and guidelines identified with lawful legislative issues in agribusiness, while the verifiable methodology is utilized to depict the improvement of the example of law definition in the horticultural area since the old request, new request, and change period.

\section{Discussion}

Economic globalization is a form of international economic integration in the national economic system that recognizes unlimited openness.[5] Furthermore, according to the IMF's opinion, economic globalization is a process of sharing world economic activities that is engulfing all communities in various countries by taking three forms of activity, namely international trade, foreign direct investment, how to describe the history of the formation and enforcement of laws in agriculture from the old order era to the reform era. Legal Politics in Agriculture in the Old Order Era Agricultural law politics in the old and new orders left a huge burden for the government in the reform era. This is because there are many problems in agriculture which are the legacy of agricultural policies in the two eras. In the old order era (1945-1967), the main focus of agricultural law politics was directed at efforts to:

a. the nationalization of Dutch plantations; 
b. increasing food production by establishing programs and intensifying extension programs through the Village Community Education Center (BPMD); and

c. settlement of agricultural land disputes which were later programmed into land reform.

The government in the old order era formulated the Standing on Your Own Feet (BERDIKARI) program which was realized through: a) equity programs 23 The nationalization of Dutch plantations was an effort by the Indonesian government to assert the independence of the Republic of Indonesia by way of take over colonial assets in Indonesia. To support these efforts, the Government issued Law Number 24 of 1954 concerning Supervision of the Transfer of Rights to Plantation Lands which aimed to regulate the transfer of rights to plantation lands which were originally under Dutch control. The existence of this law as a positive legal instrument to resolve the status of plantation land after the nationalization of plantations controlled by the Dutch. The form of settlement of land status is to regulate clearly and in detail regarding the transfer mechanism, including legal protection for erpacht and opstaal rights holders before the issuance of this Law. [6]

Efforts to increase the yield of agricultural products are carried out to increase the amount of food crop production, especially rice. This is due to the low growth of rice production at the beginning of Indonesian independence. In 1950, the government imported 334 thousand tons of rice. Meanwhile in 1957 the number of imports was reduced to 563 tons. But in 1958 and 1959 it increased again to 681 thousand tons and 800 thousand tons. The increase in rice imports has burdened the state because it has reduced foreign exchange earnings since 1950 . [7] The cause of the reduced production of agricultural products is caused by overlapping land ownership which causes the status of land ownership to be unclear. This was as a result of the enactment of land leases and the surrender of land owned by residents to be planted with commercial crops to be handed over to the invaders. So that the way to open agricultural reform is none other than solving agrarian problems. Several agrarian regulations produced include Law Number 28 of 1956 concerning Supervision of the Transfer of Rights to Plantation Lands, and Law Number 29 of 1956 concerning Regulations and Actions Regarding Plantation Lands, Law No. Number 1 of 1958 concerning the Elimination of Particle Lands, Law Number 7 of 1948 concerning the Transfer of Agrarian Duties and Authorities, and Law Number 5 of 1960 concerning Basic Regulations on Agrarian Principles. In the early days of Indonesian independence, regulations regarding the agricultural sector tend to regulate a lot about plantations.

This was a result of the Dutch and Japanese colonialism which forced farmers to grow rice and the majority of trade products were none other than plantation products people's prosperity through land reform which was initiated through the issuance of Law Number 5 of 1960 concerning Basic Agrarian Regulations (UUPA) and its implementing regulations; and implementing the Special Prosperity Plan (RKI) program aimed at developing the agricultural sector by developing methods for new ways in farming techniques, building supporting institutions for production facilities, and others. Unfortunately, the program is not running effectively. Legal Politics in the Agricultural Sector in the New Order Era In the New Order era (1968-1998) legal strategy in agriculture was directed to achieve three things, namely:

a. strengthen national food security;

b. spur economic growth and improve national economic stability; and

c. increase farmers' income.

The direction of agricultural policy is prioritized to spur the development of national rice agribusiness and implement it consistently and sustainably. The implementation of the national rice agribusiness development strategy is carried out comprehensively and integrative involving analysis in the social and political economy sectors so as to achieve food security. 
Strengthening national food security is defined as an effort to ensure the rice needs of the population so that food security policies are focused on providing rice. Programs run by the government in the new order era to achieve food security include:[8]

a. Green Revolution;

b. Community Guidance Program

These programs are not working effectively. due to:

a. The government's commitment to land reform and ownership of company shares is not strong and concentrated because the state leadership is too busy with political affairs;

b. confrontational and revolutionary policies against large-scale companies that control very large lands, especially those with the status of foreign companies by carrying out nationalization actions;

c. There is an attitude of distrust of the government from one of the existing political party forces and then taking unilateral land expropriation actions from the landlords;

d. Poverty is rampant.

The Green Revolution is an agricultural strategy developed to increase food ingredients.

One way that is applied is to create several varieties of food plant seeds such as rice.[9] What is striking about the agricultural law strategy in the New Order era is the dominance of the involvement of foreign industries in food security programs, especially in the field of providing chemical fertilizers and pesticides. The existence of foreigners is supported by Law Number 78 of 1958 concerning Foreign Investment which was later updated to Law Number 1 of 1967 concerning Foreign Investment (FDI Law).

Foreign capital is considered very important to help encourage the country's national development, even though the PMA Law is considered by some to be one of the legal products with a liberal-capitalist pattern. This green phenomenon occurs on the African continent and most Asian countries, including Indonesia. Technically the Green Revolution is carried out by dramatically increasing grain production in areas where water can be controlled or irrigated, the rate of adoption of high-yielding varieties, fast-acting fertilizers being used in large quantities, major pests and diseases controlled chemically and/or resistance varieties, and attractive incentives in the form of subsidies or price support.

Tejoyuwono Notohadiprawiro, Green Revolution and Soil Conservation, paper presented at the Natural Resources Conservation Course Batch 1 of the Special Region of Yogyakarta on 21-27 June 1995, p. 5. In its implementation, the Green Revolution was realized in the form of Panca Usaha Tani which was successfully realized due to the synergy of assistance from upstream to downstream so as to achieve production targets. Unfortunately, this program was discontinued in 1968 because it caused several problems, one of which was the increase in credit packages for agricultural production facilities which were not properly monitored, resulting in credit defaults in the process of repayment.[10]

The Community Guidance Community Guidance Program during the Pelita I era which was held in 1968-1970. This program collaborates with foreign agricultural production facilities (saprotan) providers such as Mitsubishi and CIBA to become suppliers and distributors of agricultural inputs as well as technical consultation to farmers. [10] In addition, the government is also collaborating with the International Rice Research Institute (IRRI) in the Philippines to provide superior rice seeds. The existence of IRRI periodically replaces local rice seeds and even IRRI varieties of rice seed products are developed in collaboration with the Indonesian Agricultural Research and Development Center. This program is in contrast to the Green Revolution program where the role of the community is replaced by foreigners. 
The real result of this program is the introduction of the use of manufactured seeds and agricultural chemicals in rural Indonesia which causes outbreaks of leafhoppers due to the use of pesticides which also kill the natural enemies of planthoppers. As a result of the pest explosion, in 1975 it caused crop failure. Due to crop failure, farmers are unable to meet the rice supply targeted by the Government. [10] Self-sufficiency in rice is a farmer-guidance-based program that has been running since 1984. All government officials and sectors are mobilized to support the implementation of the rice self-sufficiency program by all means. Rice self-sufficiency is a unifying program between the security forces and the government to achieve the goal of increasing the domestic supply of rice. Thanks to high political commitment, consistency, and continuous support from a large government budget and the patriotic sacrifices of farmers, the program to increase national rice production was successful quantitatively so that Indonesia's status changed from being the largest rice importer in the world to being self-sufficient in rice in 1984. Although rice self-sufficiency was considered a success, towards the end of the New Order government the agricultural sector was slowly abandoned. Agriculture, which was originally the main sector of the country's economic development object, began to be shifted to the industrial sector.

Law Number 7 of 1994 concerning Ratification of the Agreement Establishing the World Trade Organization. The goal to be achieved by the WTO is to reduce tariffs on trade commodities, including reducing barriers to the import-export process between member countries. This is the reason why many deregulations of export-import licensing have been carried out in Indonesia since 1989. This condition was exacerbated by the existence of loan assistance from the International Monetary Fund (IMF) after the decline in the rupiah exchange rate. (LoI) aims to permanently integrate the global economy into the national economy through the implementation of certain policy recommendations. 35 These policy recommendations are capitalist liberal policies and are known as the Washington Consensus.

Legal Politics in Agriculture in the Reformation Era Agricultural conditions in the reform era began with bearing the impact of the economic crisis to absorb the abundance of informal and urban sector workers, resulting in the resilience of the agricultural sector being weak.37 Apart from the economic crisis, political transition and decentralization became the cause of the blurring of agricultural policy at the beginning of the reform era. Precisely, after the Letter of Intent (LoI) dated October 31, 1997 signed by the Minister of Finance Mar'ie Muhammad and the Governor of Bank Indonesia J. Soedradjad Djiwandono accepted the IMF recommendation and requested an IMF Stand-by Arrangement for three years. In the LoI, the government is committed to implementing economic policies in accordance with IMF recommendations, which consist of macroeconomic policies, banking restructuring, and structural reforms. [12] The day after the LoI was signed, the government immediately carried out IMF directives by liquidating 16 troubled banks. As a consequence, BI had to provide a bailout fund to return depositors' funds, which became known as the Bank Indonesia Liquidity Assistance (BLBI) fund. By the end of 1997, BI had disbursed BLBI funds of up to Rp 48.8 trillion.

The term Washington Consensus was introduced by John Williamson in 1989. The term refers to ten points of policy recommendations recommended by the IMF, World Bank, and US Treasury Department to developing countries hit by the economic crisis. The recommendations according to the Washington Consensus include: 1) liberalization of free trade, (2) capital market liberalization, (3) floating exchange rates, (4) market-determined interest rates, (5) market deregulation, (6) SOE privatization, (7) transfer of subsidy budget to the public or social sector, (8) disciplined fiscal policy/balanced budget, (9) tax reform, (10) protection of property rights and copyrights. Muhammad Amien Rais, Agenda Urging the 
Nation: Save Indonesia through the economic decentralization package, the central government has given some of the authority to manage agriculture to local governments. After the issuance of the economic decentralization policy, agricultural development activities tended to decline. This is because agricultural development requires large costs while the return cannot be directly obtained by investors. Investors are more interested in investing in the fields of industry, mining, forest exploitation, and tourism.[13] In addition, political factors are a constraint for not optimal agricultural development programs due to differences in perceptions between the executive and the legislature. The differences in perceptions above certainly have an impact on the preparation of the Plan Regional Development and determination of budget allocations. In addition to the issue of economic decentralization, the direction of agricultural policy in the reform era was also faced with the issue of foreign investment. Foreign investment is regulated in Law Number 25 of 2007 concerning Investment.

Based on the Law, the Government issued Presidential Regulation Number 44 of 2016 concerning List of Business Fields Closed and Business Fields Open with Conditions in the Investment Sector. The Presidential Regulation opens sectors that are open to foreign capital flows, such as: 40 a) plantation seed industry business with an area of 25 hectares or more with a maximum capital of $95 \%$; b) Plantation business with an area of 25 Ha or more up to a certain area without a processing unit. Foreign investors have a maximum investment allocation of $95 \%$ with an average obligation to fulfill plasma plantations of $20 \%$; c) Plantation business with an area of $25 \mathrm{Ha}$ or more integrated with a processing unit with 3839 capacity equals or exceeds a certain capacity. [14] On average, foreign investors have the opportunity to allocate $95 \%$ of their capital with $20 \%$ of plasma plantation liabilities; and d) Businesses with a capacity equal to or exceeding a certain capacity. On average, foreign investors have the opportunity to allocate $95 \%$ of their capital with liabilities plasma plantations by $20 \%$. The four agricultural sectors (read: plantations) that are open to foreign investment above have an allocation of the amount of investment ranging at a rate of $95 \%$, including in other strategic business fields such as the maritime, forestry, health, and finance sectors. This confirms that the government has relied on foreign investment to increase domestic agricultural development.41 In addition to problems in the realm of granting authority and investment, land is the most essential issue in agricultural development activities. one of the many complex agricultural problems in the reform era.

If reviewed, the reason for the issuance of Law No. 41 of 2009 on Protection of Sustainable Food Agricultural Land (Law No. 41 of 2009) is to protect agricultural land from the onslaught of development in order to support national food security. It's just that the noble purpose of this Law has encountered many obstacles, including government policies related to the preparation of the Regional Spatial Plan (RT/RW) and the lack of guidance and supervision of PLP2B. The government's obligations can be carried out in the form of setting tariffs on agricultural commodities, entry points for agricultural commodities from abroad in the customs area, administrative requirements and quality standards, balanced agricultural product market structures, and food price stabilization policies. These provisions should be able to become a legal instrument to improve the standard of living of farmers. However, Law no. 19 of 2013 still has various legal issues, such as: 1) the basic concept of protecting agricultural land is not in line with the spirit of Law no. 5 of 1960;2) there are several norms that deviate from the concept of state property rights (HMN) which place farmers as tenants and not owners; 3 ) the existence of this Law actually encourages the occurrence of feudalism in the agrarian field; 4) trigger speculation and commercialization of land tenure and management.45 These four problems are based on the concept of land reform which is not 
finished yet. The existence of Article 55 paragraph (1) of Law no. 19 of 2013 confirms that the Government and Regional Governments in accordance with their respective authorities are obliged to guarantee the availability of agricultural land. One of these guarantees is carried out by guaranteeing the area of agricultural land (Article 55 paragraph (2) letter 45 Consortium for Agrarian Reform, Expert Council of KPA Unraveling Falsehood of Law on Protection and Empowerment of Farmers.[15]

Steps that can be taken by the government and local governments to guarantee the area of agricultural land are to provide convenience for farmers to obtain free state land designated or designated as agricultural areas (Article 58 paragraph (2)). Unfortunately, the process of granting access to manage agricultural land is charged with a lease model, not property rights. So, in addition to having to spend capital to use the land, farmers also need to spend capital to rent the agricultural land.

Although the concept of land lease as regulated in Article 69 of Law no. 19 of 2013 has been canceled by the Constitutional Court through the Constitutional Court Decision No. 87/PUU-XI/2013, but until now there is no clarity regarding its implementation. In addition, the regulation of agricultural insurance as regulated in Article 7 paragraph (2) letter $g$ of Law no. 19 of 2013 is also still reaping problems. The implementation of agricultural insurance is faced with several fundamental challenges, such as: a) institutional challenges related to institutions, legal and regulatory frameworks, and the role of insurance companies in the framework of financing partnerships for agricultural insurance development; b) financial challenges related to cost efficiency of agricultural production risks; and c) technical challenges related to risks in agricultural production, provision of infrastructure and weather information services.

Development of Indonesian Agricultural Law Politics in Facing Global Challenges Global challenges in the agricultural sector today are introduced through economic globalization which is manifested in the form of free markets and international trade in agricultural products.[16] Economic globalization is seen as providing. Basically, economic globalization has occurred since the New Order era, precisely after the Indonesian government ratified the WTO in 1995.

Economic globalization is basically intended to make the whole world as a single market which is characterized by free movement of capital, goods and services through reducing tariffs, eliminating non-tariff barriers, eliminating subsidies, increasing market access, and the principle of non-discrimination in international trade. The impacts of economic globalization include increasing international economic roots which are based on technological developments but on the other hand the program will cause inequality because not all parties benefits because it provides easy access to buying and selling goods freely through the free market.

The existence of economic globalization has slowly shifted the realm of the country's economic policy from democratic to liberal. Economic globalization is intended to restructure the economic systems of developing countries in the form of liberalization of domestic trade and investment regulations, as happened in the New Order era.48 The real implications of economic globalization can be seen in the practice of free markets. The free market, if analyzed according to international trade theory, is an unimpeded trade between countries, thus providing an opportunity for each country to highlight its superior products. 49 However, economic globalization has adversely affected the condition of farmers, especially small farmers.

Farmers are required to compete with food distribution systems in global markets controlled by multinational companies. In addition, farmers must also be faced with increasing 
production costs due to ineffective fertilizer subsidies. Such conditions become a threat to the survival of domestic agriculture. Legal politics to face global challenges, especially free markets and international trade, one of which is conceptualized with implementation based on economic democracy. Economic democracy is sovereignty in determining the direction of economic policy by the people. Economic democracy is the main feature of the alignment of the economic system prevailing in a country. The idea of economic democracy has been regulated in Article 33 of the 1945 Constitution of the Republic of Indonesia (UUD NRI).

However, in practice the Indonesian government did not stop subsidies. However, the government still provides fertilizer subsidies to farmers with different total subsidies each year depending on the budget plan drawn up. Based on the simulation results, the abolition of the fertilizer subsidy elimination policy has a negative impact on rice production. This caused Indonesia's rice supply to decline by $18.91 \%$. [17]

The minutes of the BPUPKI Session on the formulation of Article 33 of the 1945 Constitution of the Republic of Indonesia and the thought of Hatta as the initiator of Article 33 of the 1945 Constitution of the Republic of Indonesia indicate that the nature of economic democracy mandates the creation of a national economy that has the following characteristics: (1) a democratic economy marked by increased participation of the people in control of capital and non-economic factors of production (economic resources) controlled by individuals, groups, certain groups, and foreigners; (2) the participation of the people in the control of capital and production factors is carried out with a joint effort based on the principle of kinship or mutual cooperation or cooperation not individualistic; (3) the increasing participation of the people in the control of capital and production factors in its development creates equal employment opportunities and people's income until finally realizing people's welfare instead of creating the accumulation of wealth for individuals, groups, certain groups, and foreigners (capitalistic); (4) the process of democratization of the economy carried out by intervention or the active role of the state in regulating the economy (planned economy) instead of a free market economy with the minimum possible role of the state; (5) the creation of economic independence; (6) the role of the private sector in controlling capital and production factors is regulated and adjusted to the government's economic planning; (7) open to foreign participation in the economy with the main priority through foreign aid or loan programs (which are free from political intervention and do not cause dependence and are in accordance with development planning) while foreign investment is the alternative.

Hatta also referred to the seven characteristics of the national economy as cooperative socialism. The seven characteristics above can essentially be understood as an economy that is

democratic and nationalist. This nationalist-democratic economy is expected to be realized through national economic development carried out by the government. Based on the above concept, there are 2 (two) things that must be emphasized in order to restore the legal politics of the agricultural sector so that it can compete in the free market, namely: a) formulating legal politics based on economic democracy and b) improving the mentality of policy makers, especially coordination between the Minister of Agriculture and the Ministry of Agriculture. Minister of Trade. Law is translated as a tool to achieve goals and achieve goals, so legal politics is defined as the direction that must be taken in making and enforcing laws in order to achieve the ideals and goals of the nation.

Legal politics is an effort to make law a process of achieving ideals and goals. In order to achieve the expected goals and objectives, the legal political development process must pay attention to the following rules:

1. Public legitimate governmental issues should consistently prompt the country's beliefs of an equitable and prosperous society dependent on Pancasila. 
2. Public lawful legislative issues should be pointed toward accomplishing state objectives, specifically:

a. Protecting the entire nation and the homeland of Indonesia;

b. Advance the overall government assistance;

c. Enrich the life of a nation;

d. Execute world request dependent on opportunity, timeless harmony, and civil rights.

3. National legal politics must be guided by the values of Pancasila as the basis of the state, namely:

a. In view of strict ethics;

b. Regard and ensure common freedoms without segregation;

c. Join all components of the country with all its early stage ties;

d. Putting power under the force of individuals;

e. Building social justice.

4. If it is related to the ideals of the rule of law in Indonesia, the politics of national law must be guided by the obligation to:

a. Protecting all elements of the nation for the sake of integration or the integrity of the nation; - Realizing civil rights in the economy and society;

b. Acknowledging popular government (power of individuals) and nomocracy (sway of law);

c. Making strict resistance dependent on politeness and humankind. Endeavors to accomplish objectives and goals with these establishments and rules require a public general set of laws based on Pancasila, in particular an overall set of laws that takes and consolidates different qualities and interests, social qualities, and the idea of equity into one kaleidoscopic legitimate bond by taking social components.

Such a legal system brings together the good elements of the three value systems and puts them in a balance relationship including: a) a balance between individualism and collectivism; b) The balance between rechtstaat and the rule of law; c) balance between law as a tool to realize and law as a mirror of values that live in society; d) a balance between religious values and a secular (theodemocratic) or religious nation state. The gist of the above legal political development procedure is used as a means to formulate an agricultural strategy policy direction based on food sovereignty, containing a balance of individual and collective interests, and paying attention to Pancasila values. The development of legal politics in the agricultural sector must maintain a balance of three triangulation points originating from values/norms, religion, and culture so as to form a balance in the objectives of the political development. Specifically, the above legal political development model must be accompanied by the development of strategic agricultural steps which include: a) increasing the income and standard of living of farmers; b) expanding employment and business opportunities; and c) meet demand and expand the market. Meanwhile, agricultural efficiency must be implemented with indicators of achieving the highest agricultural products in order to provide opportunities for farmers.

\section{Closing}

In light of the depiction above, it very well may be inferred that: First, the legitimate governmental issues of farming in Indonesia during the Old Order time would in general be aimed at agrarian land inventories and endeavors to nationalize Dutch ranches. During the New Order time, the heading of lawful governmental issues in the agrarian area was isolated 
into two examples, specifically the example towards food power through the Green Revolution and Rice Self-Sufficiency and the subsequent example was semi-industrialized agribusiness, which was set apart by the participation of unfamiliar organizations as food makers.

During the reformation period, legal politics in domestic agriculture tended to lead to foreign interests as a result of Indonesia joining the WTO. This can be seen from the dominance of foreign regulations both in terms of the distribution of GMO products, land tenure that is prioritized by corporations, the concept of sustainable food land protection that is not integrated, and the condition of farmers who are not prosperous. Second, the idea of developing legal politics in the agricultural sector in order to face global challenges (ius constituendum) is pursued by implementing a legal political development system based on the values of Pancasila.

Legal politics based on Pancasila values can be applied by internalizing economic values based on democracy as initiated by Moh. Hatta. Specifically, the agricultural law political development model must also be accompanied by actions to develop agricultural strategic steps as has been presented in the discussion above on. As for suggestions to resolve the issue of the direction of the political discussion of agricultural law in Indonesia, first, the government in formulating the direction of agricultural policy must dare to look at the reality experienced by domestic farmers and domestic market conditions in order to balance the quantity of imported products and domestic products. Second, increasing public participation openly in discussing the composition of agricultural policies, so that the resulting policies are not only in favor of the interests of foreign investors or international business actors.

\section{References}

[1] Latif, Yudi. Plenary State, Historicity, Rationality, and Actuality, Pancasila. Gramedia Pustaka Utama, Jakarta, p. 2.3 (2011)

[2] Afwit Freastoni and Sirajudin. Legal Politics of Agricultural Land Protection and Farmer's Rights as Instruments to Realize Sustainable Food Security in Indonesia. Journal of the Constitution PUSKASI FH Universitas Widyagama Malang Volume III Number 2 November 2010, p. 149.

[3] Table 1 Area of Agricultural Land in Indonesia in 2003-2009 Source: Central Bureau of Statistics 2003-2009

[4] Salikin, Karwan A. Sustainable Agricultural Systems. Kanisius Publishers, Yogyakarta, p. 13. 2003.

[5] Suyanto, Bagong. Economic Sociology, Capitalism and Consumption in the Era of Post-Modernism Society. Kencana, Jakarta, p. 93 (2013).

[6] History of Indonesian Agricultural Development,

[7] Nugroho, Tri Wahyu. Impact of Agricultural Development Policies on Poverty Reduction. Thesis, Master of Economics and Management, Bogor Agricultural University, (2006)

[8] Ismail, Nurhasan. Arah Politik Hukum Pertanahan Dan Perlindungan Kepemilikan Tanah Masyarakat. Jurnal Rechts Vinding: Media Pembinaan Hukum Nasional [Online], 1.1, 33-51: (2012)

[9] Nugroho, Wahyu Budi, "Economic, Social, and Political Constellations in the New Order Era", the paper was presented in commemoration of the 19th Anniversary of the Reformation which Titi WS., Mardjo, and Tutut FMP. Politics of Agricultural Law... 
607 organized by BEM-PM Udayana University at the Faculty of Economics and Business on 27-28 May (2018)

[10] Soetoprawiro, Koerniatmanto. Introduction to Agricultural Law. Gaperindo, Jakarta, p. 27-31 (2013).

[11] Pantjar Simatupang and I wayan deer, Rice Agribusiness System Development Policy, in the Indonesian Agency for Agricultural Research and Development, Indonesian Rice and Rice Economy, p. 35-38.

[12] Indonesia Letter of Intent, October, 31, 1997, available at https://www.imf.org/external/np/loi/103197.htm, accessed on 10 August 2018.

[13] Henny Mayrowani, "Agricultural Development in the Era of Regional Autonomy: Policy and Implementation.” Agro-Economic Research Forum, Volume 30, Number 1, July 2012, p. 36.

[14] Presidential Regulation Number 44 of 2016 concerning List of Closed Business Fields and Open Business Fields.

[15] Consortium for Agrarian Reform, KPA Expert Council Exposing Falsehoods of the Law on the Protection and Empowerment of Farmers, Accessed via https://www.kpa.or.id/news/blog/dewan-pakar-kpa-bongkar-kepalsuan-uuperlindungan -dan-pemdayaan-petani/ on October 15 2018, at 14.24 WIB. Titi WS., Mardjo, and Tutut FMP. Agricultural Law Politics... 599 b Law no. 19 of 2013).

[16] Djunedi, Praptono. Analysis of Agricultural Insurance in Indonesia: Concepts, Challenges, and Prospects. Borneo Administrator Journal, Volume 12, Number 1, p. 13-47 (2016)

[17] Hermawan, Iwan. Analysis of the Impact of Urea Fertilizer Subsidy and TSP Policy on Rice Production and Achievement of Food Self-Sufficiency in Indonesia. Journal of Economics \& Public Policy, Volume 5, Number 1, June. p. 75 (2014) 